\title{
The tragic consequences of the collapse of the earth's surface within the mining allotment of Ordzhonikidze mine
}

\author{
Oleksandr Ye. Lapshyn, Oleksandr O. Lapshyn, and Mykola Khudyk $^{*}$
}

Kryvyi Rih National University, Labor protection and civil safety Department, Kryvyi Rih, 50027, Ukraine

\begin{abstract}
The purpose of this study is to draw the attention of scientists and mining workers to the importance of working off mineral deposits within the permissible parameters of mining and technical production, the failure of which leads to tragic consequences. Based on the analysis of physical data of the rock massif and the geomechanical condition of the exhausted space within the mine field, the causes of disturbances of the stability of the inter-dimensional pillar, its deformation and displacement were determined. The negative and dangerous factors of underground mining are given, which lead to the formation of large cavities, which are kept from collapses due to the inter-dimensional pillar and the thickness of the rocks that supported it. An analysis of the field development violations is given regarding the application of inappropriate systems of development, legislation, regulations, and inefficient design decisions that led to the accident that resulted from these violations. The actual consequences of the accident, which resulted in extensive destruction of the earth's surface, human casualties, seizure of cars, communications, buildings, roads, etc., are presented. Recommendations are given to prevent the collapse of the earth's surface, the destruction of buildings, and the death of people.
\end{abstract}

\section{Analysis of research and publications}

A great deal of research has been devoted to the study of the causes and consequences of violations of the technology of underground mining of iron ore deposits, which lead to uncontrolled destroy of safety pillars and the collapse of the earth's surface. Some of these studies explain the uncontrolled destruction of safety pillars due to the lack of proper monitoring of the state of the mountain, disturbed by mining operations, the definition of criteria for forecasting emergencies and the limits of the impact of mining operations on the stability of the earth's surface [1-4]. The authors of these studies believe that monitoring the state of the earth's surface in mining operations will prevent collapses and also avoid distortions of gas and water pipelines.

In the works related to the improvement of the concepts of systematic management of mining processes, it is emphasized that further studies should be directed to the development and improvement of existing technologies of underground mining of iron ores by systems of development with the bookmark of the produced space, which will avoid uncontrolled collapses [5-7].

From the side of the researchers, who pay attention to the necessity of developing a state program of a complex solution of the problems of the Kryvyi Rih iron ore basin (sinkhols and landslides, technogenic earthquakes, etc.). It is concluded that this is possible only at the state level with the attraction of considerable funds, specialized institutions, joint activities of mining specialists [8].
Analyzing the economic and environmental aspects of the technogenic region of Kryvbas, the study shows that the practice and accumulated experience of mining enterprises show that the costs of implementing measures to prevent possible emergencies related to the disturbance of the daily surface in the form of cracks, subsidences and sinkhols are significantly lower than losses to eliminate them [9].

\section{Setting objectives}

Underground mining is associated with the formation of voids, the untimely repayment of which or not laying them can lead to the uncontrolled collapse of safety pillars and the destruction of not only underground structures but also buildings on the surface of the mine. The purpose of this study isto identify the causes of the collapse of the earth's surface of the mine and to develop recommendations for preventing the uncontrolled destroy of barrier safety pillars within the mine field, which is set aside for the development of mineral deposits.

\section{Results and discussion}

The subsidence of the earth's surface occurred on June 13, 2010, within the mine drainage of mine Ordzhonikidze PJSC "CENTRAL GOK". An array of rocks, where the uncontrolled displacement of the earth's surface occurred, composed of deposits of ferrous

\footnotetext{
* Corresponding author: khudyk.mykola@gmail.com
} 
quartzites 18-20 $\mathrm{m}$ thick, has dismemberment with geological disturbances. Under the oxidation zone, which extends to a depth of 280-380 m, magnetite quartzite was extracted by treatment chambers in the southern and northern wings of the mine. As a result of the ore extraction, waste spaces were formed in both wings from 120 to $200 \mathrm{~m}$. These waste spaces were entirely separated, partially filled with rock, which supported the pillar at its bottom. The array of undermined rocks rested on the rear, which was the mainstay of the north and south wings of the minefield.

The geomechanical condition of the undermined rock massif was such that equilibrium could be formed, since it became a lever whose place of pinching was the unbroken indigenous rocks, and the point of displacement was a pillar. This load concentrated the load from the undermined array of both wings, as from a lever. Besides, the undermined array could be displaced by layering, since within the minefield, it was dismembered by geological shifts, which contributed to its weakening. The weakened fossil mass was further exacerbated by the existing collapse zones created by the mining of rich ores.

The state of the pillar is evidenced by three of his dumping, which occurred in 1988 (two years after its formation), with the thickness of the pillar of the project being $30 \mathrm{~m}$, and in places of dumping remains up to 15 $\mathrm{m}$. Further dimensions are not available due to the difficult approach to measurements, but the state has increased due to the direct mining of ore in the chamber from 2006 and next to it in 2007-2008 with a floor of $527 \mathrm{~m}$.

Thus, the undermined array of rocks of the northern and southern section rested on the pillar, and through the pillarwas transmitted to the ceiling of these chambers and, consequently, to the inter-dimensional pillar floors of $527 \mathrm{~m}$.

The pillar horizon of $-170 \mathrm{~m}$ was composed of oxidized quartzites, which are 2-3 times less than magnetite ones. It follows that the tense state of the pillar was such that any slight effect on it could lead to its destruction, and as a consequence - the destruction of the support that supported the massif, and this could contribute to the collapse of the worked out mountain range of the northern and southern section.

Slowly, for many years, the increase in the mass of the overlying rock and the plane of its outcrop caused the approaching of the limit state without showing signs of destruction. The massive explosion that took place triggered the displacement of the rock mass, resulting in a cone of influence, with the following parameters: area 165 thousand $\mathrm{m}^{2}$; collapse on the lying side of the deposit up to $80-82 \mathrm{~m}$; on the hanging side $-5-20 \mathrm{~m}$; void volume -7.0 million $\mathrm{m}^{3}$; the volume of waste space along the southern and northern sections is 7.2 million $\mathrm{m}^{3}$; used space fill factor -0.97 .

The mining circumstances in which the accident occurred are as follows. The raw material base of Ordzhonikidze mine is a deposit of magnetite (ferruginous) quartzites "South-Magnetite". This deposit is revealed by the main air-shaft of the Ordzhonikidze mine and the ventilation shaft of the mine "Chervona".
Development system - floor-chamber. The testing of inter-chamber pillars (ICP) was carried out by a surface collapse. During the mining of the magnetite quartzite deposit, the mine was guided by the design and technical documentation developed by the State Enterprise "State Institute for Design of mining enterprises "Kryvbasproekt" and the technical department of the Ordzhonikidze mine. Together with the design documents, which were studied by the State Commission for the Investigation of the Accident, scientific reports of the Scientific-research mining institute of the Kryvyi Rih National University (NIGRI KNU) on the carrying out of research work in the period from 2000 to 2009 were presented.

According to the expert commission, appointed by the decision of the special commission to investigate this accident, the design documentation was sufficient for the safe development of the field and the control of the rocks. However, during the mining process, deviations from the project timetable for stock extraction were allowed. So, ICP in the surveyor axes (-4) and (-11) was refined later by $8-12$ years, and ICP $(-3)$ axes were not refined. There were also deviations from the "The project of preparation and development of the deposit "South-Magnetite" in axes (-45) - (+40) floors 447$327 \mathrm{~m}$ ", 1987 and from the "Project No. 37 on preparation and testing of magnetite quartzites in block $(-7)$ and ICP $(-11)$ and $(-3)$ axis of floor 447-304 m", 1987.

In order to produce magnetite quartzites, a mass explosion was carried out at the Ordzhonikidze mine on June 13, 2010. The total mass of the explosive used was $65042.5 \mathrm{~kg}$. The mass explosion was carried out by blasting deep wells, as well as by lifting workstations, which housed concentrated vertical charges. The mass explosion was monitored by NIGRI KNU staff, according to a scientific agreement on the topic "Monitoring of values of seismic oscillations of the soil and shock-air waves on the condition of the construction structures of buildings and structures located in the area of blasting on the quarries and mine Ordzhonikidze".

On the day of the mass explosion, four employees of the blast management laboratory and the seismic mine were delivered to the Ordzhonikidze mine by GAZ 2217 car ("Sobol"), driven by driver V. S. Vavruk. The seismic equipment locations were determined in advance outside the minefield. After placing the observation posts, the driver V. S. Vavruk, without entering the territory of the industrial site, put the car near the construction of the mechanical workshops of the mine, in which he intended to wait for the completion of the surveillance work.

Immediately after, the explosion began an intense collapse of the daily surface, which was in the mine drainage area. At the distance of $20 \mathrm{~m}$ from the checkpoint No. 9 (CP-9) in the southwest direction there was a subsidence of the earth's surface, together with an array of pressure rocks over a clearing space of about $360 \mathrm{~m}$ in length, and in the perpendicular direction $450 \mathrm{~m}$, with a plane approximately 16 hectares. The subsidence of the earth's surface (displacement) on the side of the lying side of the reservoir was a maximum of 
$82 \mathrm{~m}$ and $20 \mathrm{~m}$ minimum, and on the side of the hanging side of the formation bed, it varied from 5 to $20 \mathrm{~m}$.

Due to the subsidence of the earth's surface, a part of the highway $20 \mathrm{~m}$ from the CP-9 went into the abyss together with three private cars and GAZ 33-023 "Gazel" cars owned by PJSC "CENTRAL GOK" and GAZ 22-17 "Sobol" owned by NIGRI KNU, which stood before the CP-9. Driver V. S. Vavruk, who was at the time of the incident in the cockpit of the car "Sobol", received injuries that are not compatible with life.

As a result of subsidence of the earth's surface, the following destruction occurred in the mine drainage zone of Ordzhonikidze mine (Kryvyi Rih):

- damaged the $6 \mathrm{kV}$ transmission line, which was one of the inputs of electricity supply to the mine;

- damaged gas pipeline, which provided gas to residents of settlements located outside the mine drainage area of Ordzhonikidze mine;

- destroyed construction of mechanical workshops of the mine;

- destroyed mine headgear of the ventilation shaft "Chervona";

- destroyed the ventilation shaft "Chervona" intended for ventilation of the mine workings of the Ordzhonikidze mine;

- the substation "Chervona" from which part of the residential sector was fed;

- requested the Brotherly Tomb of the soldiers killed during the liberation of Kryvyi Rih;

- destroyed the public highway leading from CP-9 along Brotherly Tomb to residential areas;

- destroyed the former construction of a repair shop;

- cracks of the earth's surface and the asphalt part of the site were formed on the territory of the Ordzhonikidze mine;

- three private cars, a car for cargo and passenger transportation, GAZ 33-023 "Gazelle" owned by PJSC "CENTRAL GOK" and a car GAZ 22-17 "Sobol" belonging to NIGRI KNU failed.

The State Commission of Inquiry into the accident at the Ordzhonikidze mine established technical and organizational causes and recommended such basic measures to eliminate the causes of the uncontrolled collapse of the earth's surface when developing the deposit "South-Magnetite".

Technical causes:

- unreasonable choice of systems and technologies for the development of oxidized magnetite quartzites, which by physical and mechanical properties are capable of forming the process of self-destruction;

- failure to comply with paragraph 1.2.2. Regulation on designing of mining enterprises of Ukraine and determination of mineral resources of 07.05.2004 No. 221.

Organizational causes:

- not an effective designer's service by NIGRI KNU, as it was only observational. At the same time, reports were issued that did not provide specific suggestions for creating preconditions for self-deception and did not provide an analysis of the effectiveness of the technology used;
- retreats from the "Working project of mining works and collapse of overlying rocks during mining of magnetite quartzite deposits above the horizon of $447 \mathrm{~m}$ of the Ordzhonikidze mine". Violation of the schedule of completion of the field, which did not contribute to the normal development of the process of self-destruction;

- the necessary measures were not taken, and the driver has not indicated a safe parking place at the time of the mass explosion.

Measures to protect the surfaces of mines from collapse should include:

- safety of people in buildings and sites located in the designated area;

- the preservation of objects for the purpose of their operation for the whole period of existence of the mine; - preventing the ingress of water and flooding of mines when undermined water objects;

- prevention of excess losses of minerals or their conservation;

- prevention of unjustified premature demolition or transfer of structures;

- the possibility of applying, where necessary, joint development of deposits in open and underground ways.

The main measures for the protection of objects from destruction during the underground development should be considered as follows:

1. Mining measures that reduce the deformation of rocks and the earth's surface: application of special systems of development, laying of the produced space, incomplete excavation of minerals, the introduction of the special order, and sequence of working out of reserves under-protected objects, etc.

2. Structural measures that allow to maintain permanently or extend the life of structures at deformations of the base exceeding the limit values: separation of buildings into sections using deformation seams, reinforcement of load-bearing structures employing steel rods, stretch marks and reinforced concrete belts, installation of various types and components artificial reinforcement of the foundation of the structure by creating retaining walls, cutting slits, etc.

3. Carrying out of repair and restoration works: repair of a roll and lifting of the densest parts of buildings and constructions through jacking, filling and straightening of joints of rails repair of a roll of support of transmission lines, bypass of power lines, regulation of crane ways and other work to bring the facility to a state that meets the requirements of maintenance.

4. Temporarily change the nature of the operation of the underworked object.

5. Moving structures on not underworked areas.

6. Special monitoring of the development of the displacement and the condition of the underworked objects in order to detect dangerous deformations promptly and take appropriate security measures.

7. Provision of a safety pillar for an object if other protection measures do not ensure its normal operation or are economically impractical.

The protection measures for existing sites are determined by a mining company that develops mineral resources or, on its request, by a special organization and approved in due course. Safeguards for the projected 
construction site, as well as the projected deep horizons, are selected by the design organization. When approaching the area of impact of the underground development to the protected object, the planned measures should be revised and corrected in order to prevent the occurrence of emergencies. Any construction of sites in mining impact areas must be agreed with the governmental organization responsible for the proper and safe use of minerals.

Before the drafting of the project of protection of objects located in the areas of influence of underground mining, it is envisaged that they are thoroughly inspected by a commission organized by the mining enterprise. The commission should include representatives of the company, owners of the objects to be guarded, and representatives of the organization that should design the security measures. The survey results are drawn up with an act detailing the technical condition of the object.

In the case of large-scale blasting operations, such as a mass explosion, the commission shall repeat the inspection of the blast zone and amend the security measures to determine the necessary costs of restoring the safe condition of buildings, structures, pipelines, and electrical networks and equipment. Draft measures for the protection of objects located in the area of influence of underground mining works are approved and approved following the procedure established by law and by the rules for mining operations [12]. State mining authorities control responsibility for the timely and correct selection of security measures and their implementation. Business protests against disagreement for damage, such as the destruction of structures and communications, are resolved under the law through the courts. According to the court, the mining company, which was responsible for the rockslide or collapse of the surface and the destruction of structures and engineering communications, must at its own expense, restore communications, repair, or restore the destroyed objects.

After revealing by the state commission, the nature of the process of rock displacement, the destruction of the surface, its contours, and the depths of the dips are applied to surveying cuts and plans. The scheme of the zone of deformation of the rock massif and the earth's surface is shown in Fig. 1, where shear zones, cracks, terraces, funnels, and dips are traced. This scheme was proposed in 1975 by the Institute of Mining Mechanics and Surveying (IMMS).

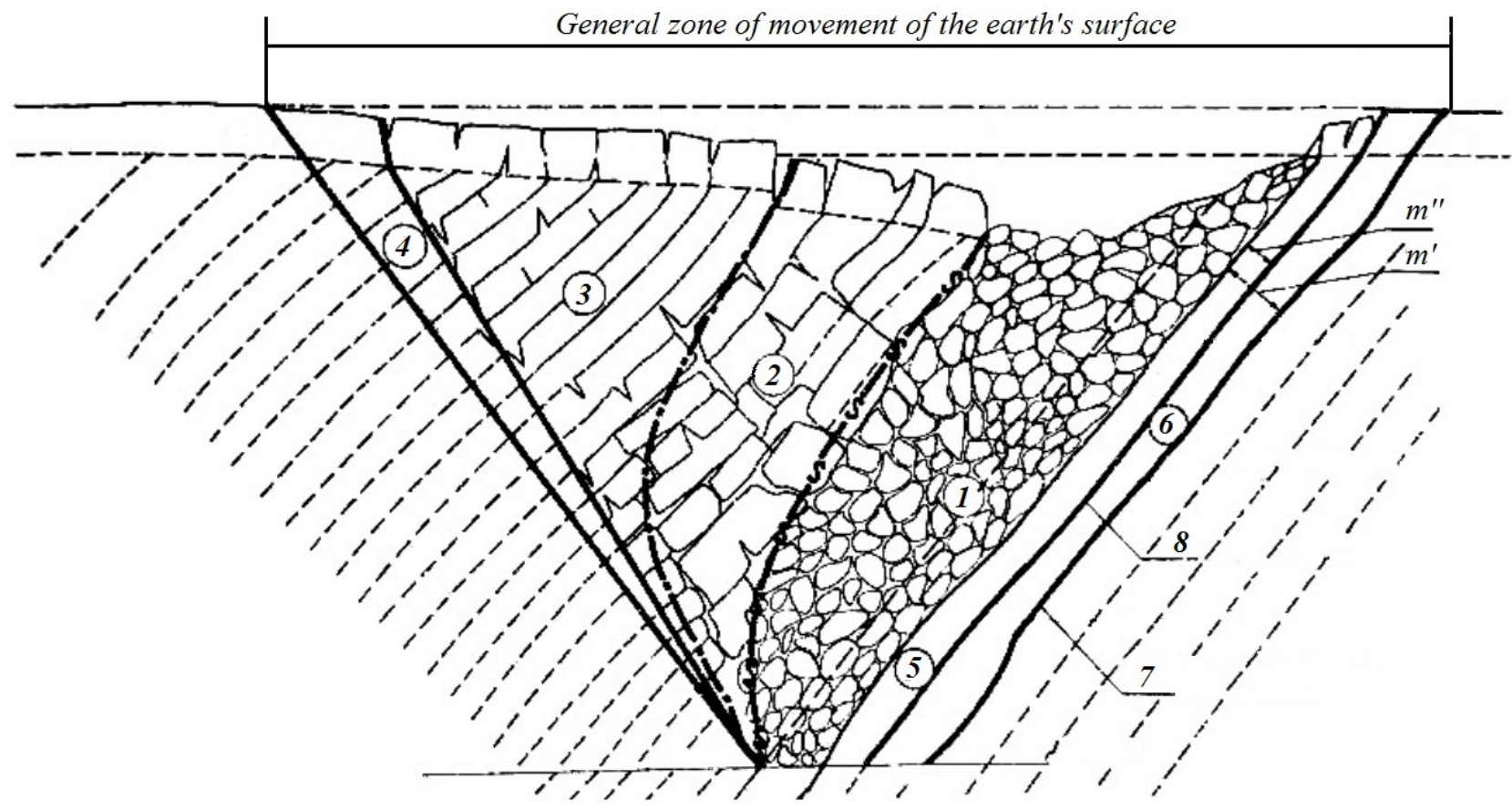

Fig. 1. The scheme of zones of deformation of the rock massif in the hanging and lying sides of the deposit according to IMMS: 1 - cone of influence; 2 - subduction zone; 3 - fissures zone; 4, 6 - smooth shift zone; 5 - fissures zone and subduction zone; 7 - displacement line; 8 - line of shear; $m^{\prime}$ - thickness of layer smooth shift zone; $m^{\prime \prime}-$ thickness of layer fissures zone and subduction.

According to the conclusion IMMS, the zone of landslide displacement is the area that is affected by underground mining if the deformations of the rock mass exceed the permissible values. In this case, in the hanging side of the deposit, shear zones are formed, which are characterized by certain physical and mechanical features:

1. The zone of cracks in which deformations are accompanied by the bending of hinged rock slabs with the formation of cracks, the loosening ratio is less than
1.1. Coming to the surface under sediment, this zone causes them to bend and stretch to form a zone of cracks on the surface of the earth.

2. The area of smooth bending is characterized by the fact that the layers of rocks bend with the formation of unconnected small cracks, the loosening ratio in this zone is close to 1.0. Depending on the deposits, this zone causes the transverse deformation of the layers and slope without breaking the continuity with the formation of a zone of smooth shifts of the earth's surface. 
3. The shifting zone of rocks along with the layer in the lying side of the deposit, in which the contact thickness of the rocks is stratified into individual packs, is displaced by the layer. Depending on the deposits, this zone causes them to shift with the formation of cracks and terraces on the earth's surface.

4. The zone of a smooth shift of rocks by layer, in which packs stratify the array, is shifted parallel to the contacts of rocks. Based on the deposits, this zone causes them to stretch and tilt without breaking the continuity with the formation of a zone of smooth shifts of the earth's surface.

Of all the forms of displacement of rocks on the earth's surface, the greatest danger is the cone of the collapse, which is formed suddenly. The sudden collapse of the earth's surface indicates the uncontrolled destruction of the safety pillars of underground chambers, which almost always leads to major accidents in mining. Timely filing of the produced space of blind deposits (deposits that do not reach the daily surface) with an mine rock (rock that does not contain iron of the required concentration) through mining workings or specially drilled wells prevents the formation of a collapse zone over the produced space and eliminates the formation the cone of the collapse.

The filling of the produced space of deposits by the bypass of the collapsed rocks and the filling of the collapsing funnels influences the process of shift and prevents the increase of the collapse zone and thereby prevents the occurrence of other cones of collapse.

According to the influence on the process of displacement of rocks and the earth's surface, the development systems in the Kryvyi Rih Basin are divided into three groups: collapsed, chamber, with the goaf stowing. When using ore collapsing systems and host rocks, the displacement parameters are determined by other influencing factors. Chamber development systems delay the displacement process but do not guarantee the appearance of dangerous landslides and deformations of the earth's surface if the system parameters do not ensure the stability of the host rocks.

The use of development systems with the goaf stowing by filled materials makes it impossible to form a zone of the collapse of rocks, funnels, dips, large cracks on the earth's surface. The parameters of the displacement process, in most cases, depending on the size of the placed deposit, the angle of its fall, the completeness of filling the space produced and the quality of the laying mixture. As evidenced by the practice of using systems with a goaf stowing by hardening materials at the mine "Ekspluataciyna" (PJSC "ZAPORIZKYI IRON-ORE PLANT"), the disturbance of the earth's surface within the mine field is not observed.

The peculiarity of the systems of development with the goaf stowing is the filling of its stowing material gradually with the advancement of the cleaning recess. This system used to prevent the displacement of the earth's surface after the ore blocks have been extracted and sometimes to create favorable conditions for working out the safety pillars. The relatively poor performance of these systems has caused their system to be replaced by collapsing host rocks. However, as mining goes down to great depths and the danger of displacement of the earth's surface increases, the value of stowing systems begins to increase, because at high mountain pressure the laying is the most effective and sometimes even the only possible means of maintaining the mountain range.

The following conditions of use are most characteristic of systems with the goaf stowing:

1. Low capacity of ore deposit - from several centimeters to $6 \mathrm{~m}$. This explained by the fact that the required amount of laying material can be obtained by carrying out main and development workings for laying the produced space of small width.

2. Large angle of the ore deposit. A gentle fall complicates the placement of the stowing material in the working excavation.

3. Resistant ores that allow for a particular time to maintain the waste space unbound.

4. Unstable mine rocks. Because tough ores with stable host rocks can work out with more productive development systems.

5. A high value of ore due to the considerable cost of its extraction.

Depending on the shape and constancy of the elements of the ore deposit, the conditions of application of different variants of systems with the goaf stowing are different. The following main groups can be distinguished:

- systems of development the horizontal slicing with the goaf stowing;

- systems of development the inclined slicing with the goaf stowing;

- overhand store systems of development with the goaf stowing;

- longwall systems of development with the goaf stowing;

- systems of development the strips the goaf stowing.

The sources of obtaining the stowing material have a significant influence on the structural elements of the system, the order, and the technology of the actual mining. There are systems for delivering stowing material from outer space and systems for receiving it within the developing block.

The basic requirements for the stowing material are as follows: the material should be cheap and easily transportable, not have a large shrinkage, be inert in the fire relation, not caking, and also when working the inter-chamber pillars, the material should be compacted and gain stability - to this end, cementing agents added to the stowing material.

Sand, crushed rocks obtained in the mine or quarry, from surface heaps, tailings of preparation plant, boiler, and metallurgical slag, etc. are used as the stowing material.

In most cases, the choice of stowing material determined by the way it transported and placed in the working excavation. On these grounds, the laying divided into dry-gravity, pneumatic, and hydraulic.

Dry crushed material, sand, tailings of processing plants, granulated slag, clay in the amount of no more than $15-20 \%$ recommended for the gravity stowing. 
For pneumatic laying, use crushed rocks of such granulometric composition: pieces of size $15-20 \mathrm{~mm}-$ $75-80 \%$; pieces of $0.5-15 \mathrm{~mm}$ size $-20-25 \%$. Clay content should not exceed 10-15\%.

For hydraulic laying, coarse-grained sands and desilted tailings of processing plants used. Great features are the stowing blend, which contains $60 \%$ quartz sand and $40 \%$ shale gravel with a particle size of not more than $20 \mathrm{~mm}$. The total shrinkage of such material does not exceed 6-9\%.

Depending on the material of the laying, the ratio of solid material and water accepted: for sand from 1:0.75 to $1: 1$; for more extensive material from 1:1.5 to $1: 2.5$. At Canada's mines, thick paste in the form of paste containing sand or desilted tailings of processing plants has become widespread. The presence of binders (clay, cement, etc.) in the stowing material gives it stability, and it allows even holding in the massif of laying workings without fastening. Such a hardened blend laying, called a "hardening laying", is gaining increasing use in mine shafts.

Given the risk of landslides and collapse of the earth's surface, structures and natural objects are protected concerning their importance, structural features, resistance to deformation, nature of the operation, condition, service life, etc. To increase the effectiveness of security measures, all objects are divided into separate categories, which are shown in the table 1.

To protect residential, public, and industrial buildings that fall into areas of dips, terraces, and cracks, mountainous measures are applied, or warning and security targets remain.

In the area of smooth landslides of the lying side of the deposit, it is allowed to preserve structures and buildings by applying constructive protection measures, which are selected according to the recommendations for designing measures to protect structures and buildings from the influence of mining.

Roads (motorways and access roads), tram lines, motorways, $110 \mathrm{kV}$ transmission lines and below, lines and cables, ground pipelines, etc., which allow eliminating the accumulated deformations are allowed to remain in areas of smooth landslides and cracks, but in projects must justify the repair, restoration, and monitoring of the surface in these areas.

All security measures must be approved by the organizations that operate the facilities. The main recommendations of the State Commission for Investigation of the Consequences of the accident, which occurred on June 13, 2010, at the Ordzhonikidze mine, are as follows:

1. Given the complexity of the mountain-geological conditions of the deposit "South-Magnetite", to clarify its physical and mechanical properties.

2. Develop a standard passport of the development system, taking into account the physical and mechanical properties of the deposit "South-Magnetite".

3. To revise the project "Measures for the protection of buildings, structures, and natural objects from the harmful effects of underground mining".
4. To carry out constant control on the part of the general designer on the observance of design decisions and schedules of working out of mineral reserves.

5. Undertakings carrying out underground workings shall introduce variants of development systems with a bookmark of the produced space from the beginning of operation of the field.

6. Perform scientific research to determine the effectiveness of methods of monitoring the state of the mountain during the development of deposits.

Table 1. Categories of objects located in hazardous areas shift of mining companies.

\begin{tabular}{|c|l|}
\hline $\begin{array}{c}\text { Protection } \\
\text { category }\end{array}$ & \multicolumn{1}{|c|}{ Protected objects } \\
\hline \multirow{5}{*}{ I } & \begin{tabular}{l} 
1. Structures of the lifting complex of mines: \\
trunks, nettles, buildings, and chambers of \\
lifting machines. \\
2. Central compressor station. \\
3. Railways, railway stations. \\
4. 3-floors and more residential buildings. \\
5. Public buildings (schools, theaters, clubs, \\
hospitals, etc.) 3 floors and more. \\
6. Industrial workshops with crane equipment \\
with a capacity of more than 15 tons. \\
7. Supports of high-voltage power lines with \\
runs between them of 300 mor more. \\
8. Railway bridges with runs over 20 m. \\
9. Water mains and pumping stations. \\
\hline 1. Ventilation and auxiliary shafts of mines, \\
buildings of the lifting complex and fans. \\
2. Main lifting shunts, drifts, main lifting \\
chambers, warehouses of explosive materials, \\
electric locomotives. \\
3. District electric and compressor stations. \\
4. Mines railway depot. \\
5. Mining electromechanical workshops. \\
6. Mine processing factories. \\
7. Administrative and household plants and \\
residential two and 3-floor buildings. \\
8. Public double floor' buildings (schools, \\
hospitals, clubs). \\
9. Water towers more than 20 m high. \\
10. Boiler rooms. \\
11. Industrial workshops with crane equipment \\
with a capacity of up to 15 tons. \\
12. Concrete loading bins. \\
1. Preparatory and threaded workings. \\
2. One-floor residential buildings, industrial and \\
office buildings. \\
3. Access mines railway tracks. \\
4. Local transmission lines. \\
5. Telegraph and telephone lines. \\
6. Highways. \\
7. Collective gardens and parks. \\
8. Cemeteries. \\
9. Overpasses of open warehouses. \\
10. Mines mechanical workshops. \\
11. Natural and artificial reservoirs. \\
12. River beds. \\
13. Water towers up to 20 m high. \\
14. Ground pipelines.
\end{tabular} \\
\hline
\end{tabular}




\section{Conclusion}

1. During the development of the deposit "SouthMagnetite", there was no proper control over the condition of the produced space by the scientific and design organizations, as well as by the management of the Ordzhonikidze mine.

2. The project for carrying out the mass explosion on June 13, 2010, at the Ordzhonikidze mine was not mentioned in the list of documents analyzed by the state commission. This project should develop all measures for the security of a mass explosion, including the designated locations of security posts and the location of private and business vehicles.

3. Lack of security posts at the approaches to the area of the mass explosion could lead to more terrible consequences of this accident (getting into the area of an explosion of outsiders from surrounding villages, cars, other transport).

4. The main responsible person for the consequences of the accident is the owner of the enterprise, which is stipulated by the Law of Ukraine "On Occupational Safety", the Mining Law of Ukraine, the Rules of Safety during the development of deposits in an underground way $[10,11,12]$, whose name is not included in the state commission report which indicates the imperfection of its conclusions.

\section{References}

1. S.I. Skipochka, V.N. Sergienko, V.B. Usachenko, Geotechnical mechanics 105, 155-160 (2012)

2. V.D. Sydorenko, O.Ye. Kulykovska, Transactions of UkrNDMI NAN of Ukraine 5(I), 306-310 (2009)

3. V.A. Driban, A.N. Feofanov, V.V. Nazimko, Ground control in mining 17, 18-23 (2009)

4. Ye.L. Zviagilskiy, Coal of Ukraine 5, 23-25 (1999)

5. V.O. Kalinichenko, O.L. Shepel, Naukovyi Visnyk Natsionalnoho Hirnychoho Universytetu 9-10, 49$51(2010)$

6. V.O. Kalinichenko, Mining Journal of Kryvyi Rih National University 100, 27-30 (2015)

7. A.F. Bulat, B.M. Usenko, A.A. Yalanskiy et al, Metodicheskoye posobiye po kompleksnoy geofizicheskoy diagnostike porodnogo massiva $i$ podzemnykh geotekhnicheskikh sistem (Toolkit for integrated geophysical diagnostics of rock mass and underground geotechnical systems). (IGTM NAN of Ukraine, Dnipropetrovsk, 2004)

8. Ye.K. Babets, Development of ore deposits 94, 3-8 (2011)

9. M.I. Stupnik, V.O. Kalinichenko, O.V. Kalinichenko, Journal of Kryvyi Rih National University 32, 246-250 (2012)

10. Zakon Ukrayiny "Pro ohoronu pratsi" (Law of Ukraine "On Labor Protection"). (Parliamentary Publishing House, Kiev, 2004)
11. Hirnychyy zakon Ukrayiny (Mining Law of Ukraine). (Parliamentary Publishing House, Kiev, 2005)

12. Pravyla bezpeky pid chas rozrobky rodovyshch korysnykh kopalyn pidzemnym sposobom (Safety rules for the development of mineral deposits underground). (Osnova, Kiev, 2017) 